OPEN ACCESS

Vol. 9, No. 1, April, 2021

Page. $44-53$

DOI: https://doi.org/10.21107/jaffa.v9i1.10523
JOURNAL OF AUDITING, FINANCE, AND FORENSIC ACCOUNTING

E-ISSN: 2461-0607 ISSN: 2339-2886

https://journal.trunojoyo.ac.id/jaffa

\title{
Over Confidence, Mental Accounting, and Loss Aversion In Investment Decision
}

Rohmad Fuad Armansyah*

STIE Perbanas Surabaya-Indonesia

\section{Article Info:}

Received: April 8, 2021

in revised form: April 20, 2021

Accepted: 26 April 2021

Available Online: 30 April 2021

\section{Keywords:}

Overconfidence, mental accounting, loss aversion, investment decision, financial behavior.

\section{Corresponding Author:}

Email: fuad@perbanas.ac.id
Abstract; The psychology related to investment cannot be ignored by individuals who want to get investment returns. Investment decisions are the most important decisions in decision making. This investment decision is a policy carried out by investors to invest in one or more assets to get more profits in the future. Overconfidence investors prefer higher risk returns to be more important than those overestimated in terms of their knowledge and lower than expected. Mental accounting considers the costs and benefits of loss avoidance decisions made by investors to protect themselves against losses. This study discusses financial problems related to community investment decisions, special investments in real assets and financial assets. The data used are 250 respondents' data on Indonesian investors who invest in Indonesian capital markets. The results showed that overconfidence and mental accounting significantly affected investors' investment decisions in the Indonesian capital market.

Abstrak; Psikologi yang berkaitan dengan investasi tidak dapat diabaikan oleh individu yang ingin mendapatkan hasil investasi. Keputusan investasi merupakan kebijakan yang dilakukan oleh investor untuk menanamkan modalnya pada satu aset atau lebih untuk mendapatkan keuntungan yang lebih banyak di kemudian hari. Investor yang terlalu percaya diri lebih memilih pengembalian risiko yang lebih tinggi menjadi lebih penting daripada yang terlalu tinggi dalam hal pengetahuan mereka dan lebih rendah dari yang diharapkan. Akuntansi mental mempertimbangkan biaya dan manfaat dari keputusan penghindaran kerugian yang dibuat oleh investor untuk melindungi diri dari kerugian. Penelitian ini membahas masalah keuangan yang berkaitan dengan keputusan investasi masyarakat, investasi khusus pada aset riil dan aset keuangan. Data yang digunakan adalah data 250 responden terkait investor Indonesia yang berinvestasi di pasar modal Indonesia. Hasil penelitian menunjukkan bahwa kepercayaan diri yang berlebihan dan akuntansi mental berpengaruh signifikan terhadap keputusan investasi investor di pasar modal Indonesia. 


\section{INTRODUCTION}

The capital market is one important component in the world economy today. Many companies use the capital market as a media to absorb investment to strengthen their financial position. The capital market facilitates investors with companies or government institutions in trading financial instruments (Tandiontong \& Rusdin, 2015). Investment decisions need to be taken by investors in order to carry out investment activities. Investment decisions refer to decisions to buy, sell or maintain share ownership (Puspitaningtyas, 2013). Decision making in general is a complex phenomenon, covering all aspects of life, covering various dimensions, and the process of choosing from the various choices available. Decision making theory is based on the concept of satisfaction, that utility is the sum of the relative pleasures or satisfaction to be achieved, to be able to determine the increase or decrease in utility in an effort to increase satisfaction. Based on this concept, the amount of utility of each individual action is maximized to achieve satisfaction. Likewise, investment decision making by investors is rational in order to maximize its utility. In this case financial accounting information is used by most investors as a consideration in its investment decisions (Puspitaningtyas, 2013). The main objective of investing is to obtain profits as dividends as well as profits from capital gains. Tandelilin (2010) states that there are several things that underlie a person in making investment decisions. First is return which is the main reason that makes someone invest. Second is the risk, the greater the expected return of an investment, the higher the risk. The third is the relationship between return and risk. The relationship between the level of risk and the rate of return is expected to be linear or unidirectional.

Investment decisions are the most important decisions in decision making. This investment decision is a policy carried out by investors to invest in one or more assets to get more profits in the future. Things that can influence decision making in investing, one of which is investor behavior. That is the attitude or behavior of investors towards the risks faced, whether they like risk (risk seekers), do they feel challenged by the risk (risk averter) or prefer to avoid risk (risk indifference). Gender can also influence individual investment decisions. Men tend to have a higher level of financial awareness than women, especially closely related to financial decision making. Investor tolerance of risk can also be influenced by the level of education, the higher the level of education tends to be the higher the tolerance of risk (risk seekers), because individuals with a high level of education must be more financially educated and understand financial management including investment (Lusardi \& Mitchell, 2011). Age also tends to influence the quality of investment, because as we get older, investor tolerance of risk tends to increase, but an investor will tend to be a risk converter when entering the period of time (Lutfi, 2011). Investors use several analytical methods in determining investment decisions. Analytical methods that can be performed by investors before making investment decisions are technical analysis and fundamental analysis. Technical analysis is a technique for predicting the direction of stock price movements and other stock market indicators based on historical market data such as price and volume information (Tandelilin, 2010:392). Meanwhile, fundamental analysis is an analysis of various factors related to company shares (Hermuningsih, 2012). This analysis can also predict future stock prices by estimating the value of the fundamental factors that affect stock prices in the future. This analysis requires the absolute role of an investor's thinking as a decision maker. Even investment of any type (real asset) requires carefulness in investment analysis.

Some studies also reveal that psychological factors can also influence investment decision making consisting of overconfidence, mental accounting and loss aversion. Overconfidence is an excessive confidence that an investor has in something. Overconfidence tends to lead to overestimation of his knowledge and to underestimate predictions made because of the excess abilities he has (Baker \& Nofsinger, 2011). So that this affects investment decision making. Overconfidence investors tend to prefer high risk with a certain level of return and prefer the type of investment in real assets, because investment in these assets requires high risk with a maximum level of profit. Several studies have shown inconsistent results regarding the effect of overconfidence on investment decisions. Research Cherono et al. (2019); Hunguru et al. (2020); S Hallale \& Gadekar (2019) shows a significant result overconfidence affects investment decisions, even Aziz \& Khan (2016); Jain et al. (2019); and Pikulina et al. (2017) shows the results of a robust, while Isidore $\mathrm{R} \&$ Christie (2019); Wulandari \& Iramani (2014) shows that there is no effect of overconfidence on 
investment decisions and Combrink \& Lew (2020) shows the results of the negative relationship overconfidence to investment decisions. Another psychology is mental accounting, which is the thought of investors who always consider the costs and benefits of decisions taken (Nofsinger \& Nofsinger, 2018).

Mental accounting is a person's economic behavior that classifies income and output based on items such as an accounting model. Mental accounting is a series of cognitive operations that are used by individuals and households to code, categorize and evaluate their financial activities (R. H. Thaler, 2011). According to this theory, individuals assign different functions to each group of assets, which are sometimes irrational and detrimental to consumption decisions and other behaviors. Another aspect of mental accounting is that money is treated differently depending on the source. For example, there is a tendency to spend more effortlessly earned money, such as tax returns, work bonuses and gifts, compared to their wages. Several studies examining the relationship between mental accounting and investment decisions have shown inconsistent results. Research conducted by Cherono et al. (2019); Hunguru et al. (2020); Isidore R \& Christie (2019) resulting in a mental accounting effect on investment decisions, meanwhile S Hallale \& Gadekar (2019) indicates a weak relationship, and Aziz \& Khan (2016); Jain et al. (2019) shows that mental accounting and investment decisions do not have a significant relationship.

Psychology related to investment is inseparable from individuals who try to get income from investments in the future. Many types of investments can be chosen by investors in accordance with the wishes and expectations of investors, including real investment and financial investment. Real investment can be in the form of investment in tangible assets, such as land, houses or gold and things can be seen in their form. This is generally done because it can have added value and can be known directly by the owner. Other things with financial investment are assets with invisible forms, but have calculated values among investors, such as written financial contracts, shares, mutual funds, bonds and other securities.

Another psychological factor that affects investment is loss aversion. Tversky and Kahneman (1991) conducted experiments on a group of individuals with beautiful mugs, then were asked to estimate the price level at which they would be willing to take off the mug (group A). While the other groups were also asked to look at the mug, and decide which price was right for him (group B). The experimental results showed that group A was much larger in estimating prices than group $B$. The results showed that, a high sense of willingness was determined by group A because of the loss of something that had been owned more than the pleasure of getting it. Gomes (2003: 696) further examines investor loss aversion in the selection of trading portfolios and volumes. The results show that investors with loss aversion will sell most of their shareholdings to protect themselves against losses. Risk aversion, this implies that investors' loss aversion will keep investors from holding shares unless they expect premium equity to be quite high.

Loss aversion is generally known in the context of lotteries or prizes (Kahneman \& Tversky, 1979; Köbberling \& Wakker, 2005; Schmidt \& Zank, 2005). However, people often experience losses that may not be measured in monetary terms such as loss of close friends or relatives, loss of trust, reputation or prestige, loss of sports titles, loss of loved ones, loss of good intentions of clients, loss of employee morale and so on investment matters. This study extends the understanding of loss aversion related to decision problems where results (consequences) may not be measured in monetary terms. Every individual tries to get a useful income for the future. This income can be made by setting aside a portion of the income you have to invest. Investment is a commitment to funds either directly or indirectly invested in one or several assets with the aim of increasing welfare in the future (Lutfi, 2011).

Loss aversion has also been used to explain how and why options without risk can depend on the initial position of the consumer. In one demonstration, Knetsch (2019) gave mugs or chocolate bars to the participants of the experiment and gave them the opportunity to store the items they had or exchange them for other items. The null hypothesis which states that there is no influence of the initial position on the choice (and implies focus only on the status of consumption) predicts that half the participants will choose to trade their goods. However, only a few of the participants (around 10\%) chose to trade, this indicates a strong tendency to stick with current possessions. This "lasting effect" by Thaler (1980) and Kahneman et al. (1990) giving the tendency to give greater value to the goods that are owned. In the related analysis, Samuelson \& Zeckhauser (1988) introduced the term "status quo bias" after documenting the tendency to maintain the status quo in decision making. Previous research examining the relationship of loss aversion to investment decisions has had various results such as Cherono et al. (2019); Hunguru et al. (2020); Isidore R \& Christie (2019) 
shows a significant relationship of loss aversion to investment decisions, and S Hallale \& Gadekar (2019) indicates a weak relationship, meanwhile Aziz \& Khan (2016); and Jain et al. (2019) results that there is no relationship between loss aversion and investment decisions. Furthermore, in this study will discuss these financial behaviors towards community investment decisions, especially investments in capital market.

\section{LITERATURE REVIEW AND HYPOTHESES DEVELOPMENT}

\section{Prospect Theory}

Prospect theory is a theory related to economic behavior that describes how people choose between alternatives that involve the probability of the risk faced, where the probability of risk is known (Verhofen, 2014). This theory states that people make decisions based on the value of the potential losses and gains compared to the end result and evaluating these disadvantages and benefits using certain heuristics. The model tries to model real life choices, instead of basing on optimal decisions and was developed by Kahneman \& Tversky (1979) as a psychological in decision making, compared to expected utility theory or it can be said that the term prospect is called the lottery.

\section{Investment Decision}

Expectation of investment is fundamental in the investment decision process. Return and risk is a direct and linear relationship, namely the greater the expected return on these assets, the greater the level of investment risk and vice versa (Tandelilin, 2010). An investment decision is a policy taken by an individual to place capital on one or more assets to gain profits in the future or a problem of how a person must allocate funds into forms of investment that will be able to gain future benefits (Wulandari \& Iramani, 2014). In short, investing decisions are the use of long-term funds. Whenever someone decides not to spend all of his current income, then that person is faced with an investment decision (Tandelilin, 2010).

\section{Overconfidence}

Overconfidence is the tendency of individuals to feel more about their knowledge, ability and accuracy of their information, or to be too optimistic about the future and their ability to control (Ackert \& Deaves, 2010). Someone with high overconfidence tends not to consider the impact of the risks that have been taken when choosing the type of investment. Overconfidence causes investors to overestimate the knowledge they have, and underestimate predictions made because investors overestimate their abilities (Baker \& Nofsinger, 2011). Research that supports the relationship between overconfidence and investment decisions are research by Aziz \& Khan (2016); Cherono et al. (2019); Hunguru et al. (2020); Jain et al., (2019); Pikulina et al. (2017); S Hallale \& Gadekar (2019).

The indicators are as follows:

a. Individual knowledge can help individuals make investment decisions.

b. Risk becomes meaningless to individuals.

Based on the description, the hypothesis proposed is:

H1: There is a significant positive influence over confidence in investment decisions.

\section{Mental Accounting}

Thaler (2011) define mental accounting as a person's behavior when separating incoming and outgoing funds as well as accounting models. In the context of real estate, Seiler \& Seiler (2010) state that investors who experience losses in their assets will be able to minimize their regrets by thinking that the return of the portfolio is greater than the loss. By not thinking about the losses just experienced, investors will feel calmer in the short term. Mental Accounting is the behavior of individuals who always use mental counting in making investment decisions by weighing the costs and benefits of all actions that the individual does (R. H. Thaler, 2011). Previous research that supports the relationship between mental accounting and investment decisions are research by Cherono et al. (2019); Hunguru et al. (2020); Isidore R \& Christie (2019); S Hallale \& Gadekar (2019).

The indicators used are as follows:

a. In investing, an investor always calculates the profits to be earned.

b. In investing, an investor always calculates the costs to be incurred.

Based on the description, the hypothesis proposed is:

H2: There is a significant positive effect of Mental Accounting on investment decisions. 


\section{Loss Aversion}

Loss aversion refers to the fact that someone will tend to be more sensitive to losses than profits. Someone is said to not want to experience loss can be seen from the awareness of losses greater than profits (Haigh \& List, 2005). Engelhardt (2003) states that loss aversion behavior that occurs in real estate can affect household mobility. Homeowners have a tendency to avoid losses to make a profit, so they will not sell their house with a loss.

Tversky \& Kahneman (1991) show the phenomenon of loss aversion through an interesting experiment. One group was given a beautiful mug, then asked to write at what price they were willing to take off the mug (X). The other group saw the mug, then asked to decide the price that was appropriate for him (Y). The experimental results show (X) far greater than (Y). These results illustrate that, feeling upset because of losing something that has been owned more than the pleasure when getting it. Previous research that supports the relationship between loss aversion and investment decisions are research by Cherono et al. (2019); Hunguru et al. (2020); Isidore R \& Christie (2019); Jain et al. (2019); S Hallale \& Gadekar (2019).

Based on the description, the hypothesis proposed is:

H3: There is a positive significant effect of Loss aversion on investment decisions.

\section{RESEARCH METHODOLOGY}

This study uses primary data of 250 respondents by collecting through an electronic questionnaire distributed to Indonesian Stock Exchange investors who are members of a brokerage company. The sampling technique used is purposive sampling with the criteria of respondents using an application provided by the stock exchange, having a minimum age of 18 years, and being incorporated in a brokerage firm.

\section{FINDINGS AND DISCUSSION}

\section{Outer Model}

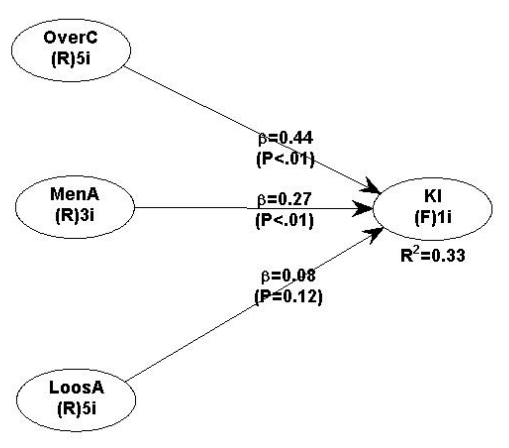

Figure 1

Outer Model

Based on the results in Figure 1, table 1 and table 2 show that all indicators have a loading factor value above 0.7 so that the validity has been fulfilled. Table 1 also shows that the composite reliability value and Cronbach Alpha have a value above 0.7, so these results indicate that the reliability has been fulfilled. It can be concluded that the indicators $\mathrm{O} 1, \mathrm{O} 2$, O3, O4, O5 are able to measure both overconfidence and LA1, LA2, LA3, LA4, LA5, MA1, MA2, MA3 variables also have a loading factor value above 0.7 so that they can measure variables well loss aversion variable, and mental accounting.

Table 1

Outer Model Result

\begin{tabular}{ccccc}
\hline & AVE & Composite Reliability & R Square & Cronbach Alpha \\
\hline ID & 1.000 & 1.000 & 0.319 & 1.000 \\
O & 0.731 & 0.931 & & 0.906 \\
LA & 0.543 & 0.798 & & 0.742 \\
MA & 0.525 & 0.726 & 0.715 \\
\hline
\end{tabular}

Source: Processed data 


\section{Inner Model}

Table 2

Loading Factor

\begin{tabular}{lrrrr}
\hline & \multicolumn{1}{l}{ ID } & \multicolumn{1}{c}{ OverC } & \multicolumn{1}{c}{ MenA } & \multicolumn{1}{c}{ LoosA } \\
\hline ID & 1.000 & 0.000 & 0.000 & 0.000 \\
O1 & -0.259 & 0.894 & 0.254 & -0.262 \\
O2 & -0.061 & 0.992 & 0.113 & 0.014 \\
O3 & -0.073 & 0.995 & 0.070 & 0.006 \\
O4 & 0.191 & 0.915 & -0.343 & 0.094 \\
O5 & 0.245 & 0.943 & -0.137 & 0.177 \\
M1 & -0.161 & 0.129 & 0.966 & -0.156 \\
M2 & 0.193 & -0.043 & 0.957 & 0.212 \\
M3 & 0.057 & -0.128 & 0.989 & 0.037 \\
LA1 & 0.206 & -0.038 & -0.147 & 0.967 \\
LA2 & 0.275 & -0.266 & -0.236 & 0.893 \\
LA3 & -0.001 & 0.008 & 0.219 & 0.976 \\
LA4 & -0.107 & 0.137 & -0.187 & 0.967 \\
LA5 & -0.448 & 0.177 & 0.598 & 0.641 \\
\hline Source: Processed data & &
\end{tabular}

The inner model describes the relationship between exogenous variables and endogenous variables. In this section the Inner model is used as the basis for testing hypotheses by looking at the coefficient of determination and path analysis. Table 3 shows the PLS-SEM analysis which is used as the basis for testing the hypothesis.

Table 3

PLS-SEM analysis

\begin{tabular}{|c|c|c|}
\hline Step of Analysis & Analysis Unit & Rule of thumb \\
\hline \multirow{4}{*}{$\begin{array}{l}\text { Measurement model } \\
\text { evaluation }\end{array}$} & Indicator reliability: Loading factor & $>0.70$ \\
\hline & $\begin{array}{l}\text { Internal consistency reliability: } \\
\text { Composite reliability and Cronbach's } \\
\text { alpha }\end{array}$ & $>0.70$ \\
\hline & $\begin{array}{l}\text { Convergent validity: Average } \\
\text { Variance Extracted (AVE) }\end{array}$ & $>0.50$ \\
\hline & $\begin{array}{l}\text { Discriminant validity: Correlations } \\
\text { among l.vs. with sq. rts. of AVEs }\end{array}$ & $<$ sq. rts. of AVEs \\
\hline \multirow{4}{*}{$\begin{array}{l}\text { Structural model } \\
\text { evaluation }\end{array}$} & Full collinearity VIF's & $<5$ \\
\hline & $t$-statistics & $>1.96$ \\
\hline & $p$-value & $P<0.005$ \\
\hline & $R^{2}$ value & $\begin{array}{l}\mathrm{R}^{2}>0.67=\text { Strong } \\
0.33<\mathrm{R}^{2} \leq 0.67=\text { Moderate } \\
0.19<\mathrm{R}^{2} \leq 0.33=\text { Weak } \\
\mathrm{R}^{2} \text { is } \leq 0.19=\text { Very Weak) }\end{array}$ \\
\hline
\end{tabular}

Source: (Chinn, 1998; Ghozali, 2014; Hair Jr. et al., 2017; Hwang \& Takane, 2004; Monecke \& Leisch, 2012)

Table 4

Hypotheses Test

\begin{tabular}{lcccc}
\hline & Correlation coefficient & t-Statistics & P value & Remarks \\
\hline Overc -> ID & 0.435 & 2.622 & $<0.001$ & Affected \\
MenA -> ID & 0.271 & 2.213 & $<0.001$ & Affected \\
LossA -> ID & 0.075 & 1.343 & 0.115 & Not Affected \\
\hline t-Table & 1.96 & & & \\
\hline Source: Processed data & &
\end{tabular}

Table 1 shows that the R-square value of 0.319 is between 0.19 and 0.33 , shows that the statistical model is weak in explaining the variables studied, namely less than $50 \%$ and the variables in the model have an influence of $32 \%$ and the rest is influenced by other variables outside the model under study. Table 4 shows that the $p$ value obtained shows that it is smaller than 0.001 and less than the a value of 0.05 , so it can be said that each variable has an influence on investment decisions in Indonesia and only the loss aversion variable has no effect on investment decisions. 


\section{Overconfidence $(0)$}

The parameter coefficient for the Overconfidence $(\mathrm{O})$ variable is 0.435 which means that there is a positive influence between Overconfidence $(\mathrm{O})$ on Investment Decisions (ID) or it can be said that investor overconfidence influences investor decision making in the investment market supported by t-statistic value 2.622 and SIGNIFICANT with a statistical $t$ value greater than $t$-table $1.96(2.622>1.96)$, so that the first hypothesis is accepted which is a positive significant influence Overconfidence on investment decisions. This shows that in making decisions, investors in the capital market are affected by overconfidence bias. This overconfidence will certainly affect investors 'investment decisions so that referring to prospect theory, investors tend to be irrational in investment choices because choices are made based on investors' overconfidence not based on in-depth investment analysis. As we know, investors need confidence in investing, but if they are too confident it can make irrational and ignore the information so that the decisions taken will be more like a lottery. The results of this study support the research conducted by Aziz \& Khan (2016); Cherono et al. (2019); Hunguru et al. (2020); Jain et al. (2019); Pikulina et al. (2017); S Hallale \& Gadekar, (2019) and differ from the results of research from Isidore R \& Christie (2019); Wulandari \& Iramani (2014).

\section{Mental Accounting (MA)}

The parameter coefficient for the Mental Accounting (MA) variable is 0.271 which means that there is a positive influence between Mental Accounting (MA) on Investment Decisions (ID) or it can be said that investor mental accounting used as a respondent influences investor decision making in the investment market as well by the value of tstatistic 2,213 and SIGNIFICANT with the value of $\mathrm{t}$ statistic greater than t-table 1.96 $(2,213>1,96)$, so that the second hypothesis is accepted namely there is a significant positive mental accounting effect on investment decisions. These results indicate that there is a significant relationship between mental accounting and investors' investment decisions in the capital market in Indonesia. This also indicates that investors tend to separate incoming and outgoing funds as well as accounting models and always use mental accounting in making investment decisions by weighing the costs and benefits of all actions on decisions taken. Referring to the prospect theory, mental accounting behavior is possible because investors are faced with a real-life choice model and a decision between potential losses and gains from their investment. These results support previous research conducted by Cherono et al. (2019); Hunguru et al. (2020); Isidore R \& Christie (2019); S Hallale \& Gadekar (2019) and differ from the results of research by Aziz \& Khan (2016); Jain et al. (2019).

\section{Loss Aversion (LA)}

The magnitude of the parameter coefficient for Loss Aversion (LA) variable is 0.075 with a t-statistic value of 1.343 and a $P$ value of 0.115 with a statistical $t$ value smaller than t-table $1.96(1.343<1.96)$, so the third hypothesis is rejected ie no there is an effect of loss aversion on investment decisions. These results indicate that loss aversion has no effect on investors' investment decision making in the Indonesian capital market, thus indicating that investors have understood the investment risks in the Indonesian capital market, this is possible if investors have sufficient information or information available on the exchange is sufficient in making decisions. Referring to the prospect theory, this is possible because investors think that the investment made is more like a choice between the gain and loss of investment. The results of this study support the research conducted by Aziz \& Khan (2016), but does not support the results of research conducted by Cherono et al., (2019); Hunguru et al. (2020); Isidore R \& Christie (2019); Jain et al., (2019); S Hallale \& Gadekar (2019). This difference is possible due to cultural differences, differences in the age of respondents, and differences in existing technological developments so that technological advances have an important role in disseminating information to investors.

The results of this study provide additional evidence and updates on previous studies. Investment decisions can be influenced by overconfidence, and mental accounting from psychological investors. Financial behavior of investors still plays an important role in investment decisions, so this study also supports the statement of Ackert \& Deaves (2010); Chen et al. (2007); Seiler \& Seiler (2010) where investment 
behavior is the main key in decision making investment and is an antecedent of trust.

This study also supports the results of Thaler \& Shefrin (1981) research which states that mental accounting as a person's behavior when separating incoming and outgoing funds as well as accounting models, while trust in institutions does not have an effect this is possible because investors tend to have different motivations -different when making investment decisions. Investors have expectations of the results of their investments in the future so it will make investors focus on the investment decision.

This study also supports the research of Kusumawati (2013) that there is a relationship between age, education and income with the factor of self-image or firm image coincidence that is related to investment decisions and the media used by investments which are easier to obtain information for decision making.

\section{CONCLUSION AND SUGGESTIONS}

The results of this study provide additional evidence and updates on research regarding overconfidence, mental accounting, and loss aversion. The results showed that overconfidence and mental accounting had a significant effect on investors' investment decisions in the Indonesian capital market, while loss aversion did not affect investment decisions. Investors have considered their expertise and capabilities in making investment decisions in addition to easy access to information technology so that investors are confident of the investment decisions taken. Investors who understand the investment climate in Indonesia, especially the capital market will be facilitated in decision making and able to make good decisions in addition to the availability of information also has an important role in the decision-making process.

Suggestions that can be given related to the development of this research are the updating of methods, data, variables and being able to more specifically see the scope of types of investment so that further research can make a different contribution to research, especially those related to behavioral economics, so that research develops and is able to reduce or eliminating limitations in this study so that future research is more comprehensive related to economic behavior. The use of other approaches is also recommended in an effort to develop this research so that more renewable research can be achieved that is able to overcome existing limitations.

\section{REFERENCES}

Ackert, L., \& Deaves, R. (2010). Behavioral Finance: Psychology, Decision-Making, and Markets. Cengage Learning: South-Western, USA.

Aziz, B., \& Khan, M. A. (2016). Behavioral Factors Influencing Individual Investor's Investment Decision and Performance, Evidence from Pakistan Stock Exchange. International Journal of Research in Finance and Marketing (IJRFM), 6(7).

Baker, H. K., \& Nofsinger, J. R. (2011). Behavioral Finance: Investors, Corporations, and Markets. In Behavioral Finance: Investors, Corporations, and Markets. https://doi.org/10.1002/9781118258415

Chen, G., Kim, K. A., Nofsinger, J. R., \& Rui, O. M. (2007). Trading performance, disposition effect, overconfidence, representativeness bias, and experience of emerging market investors. Journal of Behavioral Decision Making. https://doi.org/10.1002/bdm.561

Cherono, I., Olweny, T., \& Nasieku, T. (2019). Investor Behavior Biases and Stock Market Reaction in Kenya. Journal of Applied Finance \& Banking, 9(1).

Chinn, W. W. (1998). The Partial Least Squares Approach to Structural Equation Modelling. Modern Methods for Business Research.

Combrink, S., \& Lew, C. (2020). Potential Underdog Bias, Overconfidence and Risk Propensity in Investor Decision-Making Behavior. Journal of Behavioral Finance, 21(4). https://doi.org/10.1080/15427560.2019.1692843

Engelhardt, G. V. (2003). Nominal loss aversion, housing equity constraints, and household mobility: Evidence from the United States. In Journal of Urban Economics (Vol. 53, Issue 1). https://doi.org/10.1016/S0094-1190(02)00511-9 
Ghozali, I. (2014). Structural Equation Modeling, Metode Alternatif dengan Partial Least Square (PLS). Badan Penerbit Universitas Diponegoro.

Haigh, M. S., \& List, J. A. (2005). Do professional traders exhibit myopic loss aversion? an experimental analysis. In Journal of Finance (Vol. 60, Issue 1). https://doi.org/10.1111/j.1540-6261.2005.00737.x

Hair Jr., J. F., Matthews, L. M., Matthews, R. L., \& Sarstedt, M. (2017). PLS-SEM or CBSEM: updated guidelines on which method to use. International Journal of $\begin{array}{llll}\text { Multivariate Data } & \text { Analysis, } & 107 .\end{array}$ https://doi.org/10.1504/ijmda.2017.10008574

Hermuningsih, S. (2012). Pengantar Pasar Modal Indonesia. UPP STIM YKPN. Yogyakarta.

Hunguru, P., Sibanda, V., \& Tadu, R. (2020). Determinants of Investment Decisions: A Study of Individual Investors on the Zimbabwe Stock Exchange. Applied Economics and Finance, 7(5). https://doi.org/10.11114/aef.v7i5.4927

Hwang, H., \& Takane, Y. (2004). Generalized structured component analysis. Psychometrika. https://doi.org/10.1007/BF02295841

Isidore R, R., \& Christie, P. (2019). The relationship between the income and behavioural biases. Journal of Economics, Finance and Administrative Science, 24(47). https://doi.org/10.1108/JEFAS-10-2018-0111

Jain, J., Walia, N., \& Gupta, S. (2019). Evaluation of behavioral biases affecting investment decision making of individual equity investors by fuzzy analytic hierarchy process. Review of Behavioral Finance, 12(3). https://doi.org/ 10.1108/RBF-03-2019-0044

Kahneman, D., Knetsch, J. L., \& Thaler, R. H. (1990). Experimental Tests of the Endowment Effect and the Coase Theorem Author Experimental Tests of the Endowment Effect and the Coase Theorem. In Source: The Journal of Political Economy (Vol. 98, Issue 6).

Kahneman, D., \& Tversky, A. (1979). Prospect Theory - An Analysis Of Decision Under Risk.pdf. In Econometrica.

Knetsch, J. L. (2019). The endowment effect and evidence of nonreversible indifference curves. In Choices, Values, and Frames. https://doi.org/10.1017/CBO9780511803475.010

Köbberling, V., \& Wakker, P. P. (2005). An index of loss aversion. Journal of Economic Theory, 122(1). https://doi.org/10.1016/j.jet.2004.03.009

Kusumawati, M. (2013). Faktor Demografi, Economic Factors dan Behavioral Motivation Dalam Pertimbangan Keputusan Investasi Di Surabaya. Finesta, 1(2).

Lusardi, A., \& Mitchell, O. S. (2011). Financial literacy around the world: An overview. Journal of Pension Economics and Finance. https://doi.org/10.1017/S1474747211000448

Lutfi, L. (2011). The Relationship Between Demographic Factors And Investment Decision In Surabaya. Journal of Economics, Business, and Accountancy | Ventura. https://doi.org/10.14414/jebav.v13i3.13

Monecke, A., \& Leisch, F. (2012). SemPLS: Structural equation modeling using partial least squares. Journal of Statistical Software. https://doi.org/10.18637/jss.v048.i03

Nofsinger, J. R., \& Nofsinger, J. R. (2018). Mental Accounting. In The Psychology of Investing. https://doi.org/ 10.4324/9781315230856-6

Pikulina, E., Renneboog, L., \& Tobler, P. N. (2017). Overconfidence and investment: An experimental approach. Journal of Corporate Finance, 43. https://doi.org/10.1016/j.jcorpfin.2017.01.002

Puspitaningtyas, Z. (2013). Perilaku Investor Dalam Pengambilan Keputusan Investasi Di Pasar MODAL. Jurnal Akuntansi Universitas Jember. 
S Hallale, P., \& Gadekar, M. (2019). A Study of Behavioural Factors Affecting Individual Investment Decisions. International Journal of Trend in Scientific Research and Development, $3(6)$ 298-311. https://www.ijtsrd.com/papers/ijtsrd28100.pdf\%0Ahttps://www.ijtsrd.com/mana gement/business-economics/28100/a-study-of-behavioural-factors-affectingindividual-investment-decisions / pawankumar-s-hallale

Samuelson, W., \& Zeckhauser, R. (1988). Status quo bias in decision making. Journal of Risk and Uncertainty. https://doi.org/10.1007/BF00055564

Schmidt, U., \& Zank, H. (2005). What is loss aversion? Journal of Risk and Uncertainty, 30(2). https://doi.org/10.1007/s11166-005-6564-6

Seiler, M. J., \& Seiler, V. L. (2010). Mitigating Investor Risk-Seeking Behavior in a Down Real Estate Market. Journal of Behavioral Finance, 11(3). https://doi.org/10.1080/15427560.2010.507166

Tandelilin, E. (2010). Portofolio dan Investasi Teori dan Aplikasi. In E-jurnal Manajemen.

Tandiontong, M., \& Rusdin. (2015). Komparasi Capital Asset Pricing Model Versus Arbitrage Pricing Theory Model atas Volatilitas Return Saham. Jurnal Keuangan Dan Perbankan.

Thaler, R. (1980). Toward a positive theory of consumer choice. Journal of Economic Behavior and Organization, 1(1). https://doi.org/10.1016/0167-2681(80)90051-7

Thaler, R. H. (2011). Mental accounting matters. In Advances in Behavioral Economics. https://doi.org/10.2307/j.ctvcm4j8j.8

Thaler, R. H., \& Shefrin, H. M. (1981). An Economic Theory of Self-Control. Journal of Political Economy, 89(2). https://doi.org/10.1086/260971

Tversky, A., \& Kahneman, D. (1991). Loss Aversion in Riskless Choice: A ReferenceDependent Model. The Quarterly Journal of Economics. https://doi.org/ 10.2307/2937956

Verhofen, M. (2014). Finance. https://doi.org/http://dx.doi.org/10.2139/ssrn.2415741

Wulandari, D. A., \& Iramani, R. (2014). Studi Experienced Regret, Risk Tolerance, Overconfidance Dan Risk Perception Pada Pengambilan Keputusan Investasi. Journal of Business and Banking. https://doi.org/10.14414/jbb.v4i1.293 